\title{
STATES OF MIND AND THE HEARSAY RULE
}

\author{
EDWARD W. HINTON*
}

I

MPORTANT parts of our law are based on the assumption that human beings have various states of mind, such as intention, belief, fear, etc., which form essential elements in certain legal relations. In the field of wills there is the familiar case of equivocation, where the language is accurately and equally applicable to either of two persons, and the difficulty is solved by resort to the actual intention ${ }^{x}$ of the testator. A revocation of a will takes place when there is a destruction or mutilation of the instrument by the testator coupled with an intention to revoke.

Under the English statute of bankruptcy departure from the realm by a debtor was an act of bankruptcy, if done with the intention to hinder or delay creditors. The taking and asportation of another's chattel was a mere civil trespass or a felony according to the intention with which the act was done. In homicide "malice aforethought" cuts an important figure. A number of common law crimes require specific intent. The declarant's belief in the immediate impendency of death is essential to the admission of a dying declaration.

In deceit, intention, knowledge, and belief figure extensively.

A surprising list might be made of situations where the combination of an act and some mental state is legally important.

In the field of proof the books are full of cases sanctioning inferences or conclusions based on some state of mind.

Witnesses are discredited by proof of bias. ${ }^{2}$

Consciousness of guilt ${ }^{3}$ is regarded as evidence of the commission of a crime. The motives ${ }^{4}$ of a defendant ${ }^{5}$ or of a third ${ }^{6}$ person are relied on to prove his probable conduct.

* James Parker Hall Professor of Law, the University of Chicago Law School.

${ }^{x}$ Doe d. Hiscocks v. Hiscocks, 5 M. \& W. ${ }_{36}$ (r839).

$=$ Atwood v. Welton, 7 Conn. 66 (1828); People v. Brooks, I31 N.Y. 32I, 30 N.E. 189 (1892).

3 People v. Doody, 343 Ill. r94, x75 N.E. 436 (r93i); Davidson v. State, 187 N.E. 376 (Ind. r933); Smith v. Comm. 242 Ky. 399, $4^{6}$ S.W. (2d) $5^{1} 3$ (I932). For comments on this doctrine see Hutchins and Slesinger, Consciousness of Guilt, 77 Univ. Pa. L. Rev. 725 (1929).

4 Motive, as used by the courts, does not appear to be a state of mind, but rather something external which is the stimulus producing a state of mind, such as desire and intention, which is thought to be relevant to prove conduct. I Wigmore, Evidence (2d ed. I923), 355, § II7.

5 People v. Connolly, 253 N.Y. 330 , 17 I N.E. 789 (1930); State v. Thomas, I59 S.C. 76, I56 S.E. 169 (1930).

${ }^{6}$ Comm. v. Murphy, 185 N.E. 486 (Mass. 1933). 
The defendant's ${ }^{7}$ intention is constantly used to prove that he committed certain acts.

Messrs. Hutchins and Slesinger are inclined to criticize the judicial psychology. ${ }^{8}$

It is difficult for a layman to be sure whether psychologists really disagree as to the existence of mental states, or whether they are merely using their own jargon to describe what lawyers have been accustomed to think of as a state of mind.

Psychologists may some day upset all of our lay notions, and convince us that we have no states of mind at all, or that what we call a state of mind is something quite different from what we supposed. It may be that we are merely glorified slot machines with delusions of grandeur, and that when the right coin is inserted the mechanism automatically responds in the preordained way. This is an interesting field for speculation, but as yet rather beyond the layman's comprehension.

For the present and the immediate future, judges and jurors may be expected to use the lay psychology of general experience, for they have nothing else to go upon. The psychological expert is not likely to be received with any great enthusiasm by the courts, but rather with more suspicion than his elder brother, the psychiatrist, who has not entirely won the confidence of the bench and bar.

Judge $X$, who plans to adjourn his court from Friday afternoon until Monday, for a week-end of golf, hasn't even a reasonable doubt as to the reality of his intention, and neither have the attorneys who have been made aware of it. True, unforeseen events may deprive the judge of his holiday, but barring some perverse interposition of providence, Saturday morning's motion calendar will go over to a more convenient time. This is the every day sort of psychology which is accepted without question by the courts.

This paper, accordingly, will be confined to a discussion of the mental state exception to the hearsay rule and the everyday psychology reflected in the decisions.

If it becomes necessary or proper to prove a state of mind, there are, at least, four possible means of proof:

7 Bartram v. Stone, 3 I Conn. I59 (I862); State v. Fish, 50 S.W. (2d) 1020 (Mo. I932).

Where it is sought to prove the intention or other mental state of the adverse party by his own statements, the hearsay rule gives us no difficulty because of the general admissibility of admissions. For the controversy over the nature of admissions, see Morgan, Admissions as an Exception to the Hearsay Rule, 30 Yale L. Jour., 355 (

${ }^{8}$ Hutchins and Slesinger, State of Mind in Issue, 29 Col. L. Rev., I $_{47}$ (I929); Hutchins and Slesinger, State of Mind to Prove an Act, 38 Yale L. Jour., 283 (rg29). 
I. If the person, whose state of mind is in question, is available, the most direct method would be to swear him as a witness and examine him on the subject, on the assumption that a person is somehow directly aware of his own prior mental states. Few courts have seen any legal ${ }^{9}$ objection to this course. In practice this method is comparatively rarely used, either because the witness is unavailable, ${ }^{\text {,0 }}$ or because he is adverse in interest, and little satisfactory information can be obtained from him. In the wills cases the testator is, of course, always unavailable. In the criminal cases where the intention of the defendant is involved, the privilege against self-incrimination makes him unavailable for the government, unless he voluntarily takes the stand on his own behalf, and in that case his adverse interest makes cross-examination as to a subjective fact almost futile. It is hard to think of a case where the mental state of a disinterested third person is involved in the issue. The evidential use of some mental state of a third person is fairly common in modern times, but in such cases, if available, ${ }^{\text {II }}$ the witness normally would be called to testify to the objective facts instead of his prior mental state from which they might be inferred.

2. If, according to common experience, of which the court will take judicial notice, certain external events are likely to produce a given mental state, such mental state may be inferred from the proof of the events.

Thus the bias of a witness may be proved by his relation ${ }^{12}$ to one of the parties, or his interest in the suit. On the issue of self-defense, communicated $^{\mathrm{T} 3}$ threats are constantly received to prove the apprehension or fears of the defendant.

9 Wallace v. United States, r6 2 U.S. 466, r6 Sup. Ct. 801, 40 L. Ed. ro39 (1896); Powell v. Powell, 260 Mass. 505, I57 N.E. 639 (I927); Inter-Ocean Casualty Co. v. Stallworth, 22 I Ala. 71 (1930); People v. Ervin, 342 Ill. 42I, I74 N.E. 529 (1930).

${ }^{10}$ Since the removal of the interest disqualification, a party to the action may, and sometimes does, take the stand and testify as to his own belief, fear, intention, etc. McGaw v.

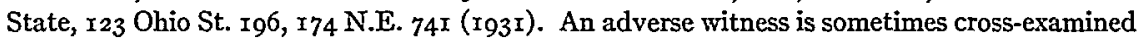
as to his state of mind in regard to one of the parties for the purpose of discrediting his testimony. More often he is cross-examined as to his prior expressions of ill will, as in Atwood v. Welton, 7 Conn. $66(\mathrm{x} 828)$ where the witness was asked as to his threats of revenge. Here the process is one of proof by the witness of his prior hearsay statement of hostility to the defendant to prove the existence of such hostility as the basis for an inference that he probably misstated the facts in his testimony in chief.

II But see Dodge v. Bache, 57 Pa. 42I (I868), where the declarant was not shown to be unavailable, though he would probably have been an unwilling witness.

${ }_{22}$ Motley v. State, 207 Ala. 640, 93 So. 508 (1922).

${ }^{13}$ Stokes v. People, 53 N.Y. $\times 64$ ( 1873 ). The cases are collected in I Wigmore, Evidence (2d ed. 1923), 5 I3,$\S 247$. 
And so where the known reputation ${ }^{\mathrm{I} 4}$ of the deceased for violence is received for the same purpose.

The proof of communicated threats or other statements to the person concerned does not involve any hearsay problem because we are not concerned with the truth of the statements, but solely with their affect on the state of mind of the hearer.

This type of circumstantial evidence is frequently available to prove certain states of mind, such as fear and apprehension. Facts furnishing a motive may lead to an inference as to intention. But in general this sort of evidence is unsatisfactory because different individuals react differently to somewhat similar conditions. For example, marital difficulties send one person to the police court, another to Reno, and a third off the dock.

More often we have no knowledge of what antecedent events gave rise to the intention of a deceased person.

3. If, according to our general experience with human behavior, certain types of conduct are regarded as manifestations of a given mental state, such conduct may be proved for that purpose. If, for example, a man on entering the house, should slam the door, kick the cat, and slap one of the children, we might naturally infer that he was annoyed.

In a large number of cases, however, significant conduct is lacking. A testator's conduct may indicate kindly feelings for his relatives, but that throws little light on his testamentary intentions.

In the case of non-verbal conduct the only question is as to its tendency to prove the state of mind in question. In the case of words regarded as conduct, we escape the difficulties of the hearsay rule so long as we are not using an express or implied assertion to prove the existence of what is asserted. For example, statements of a testator about his relatives, to prove that he was aware of the relationship, involves no problem of bearsay. And so in the case of his statements about his property to prove that he knew the nature and extent of it.

However, when dealing with spoken words some discrimination may be necessary.

It has sometimes been argued by judges and writers that, where the issue is the sanity of the testator, and some absurd statement by him is proved, e.g., "I am the Emperor Napoleon," no hearsay use is involved because we are not seeking to prove that he really was Napoleon, and hence that we are making a purely circumstantial use of his words to prove

is People v. Rodawald, r77 N.Y. 408, 7o N.E. I (1904); McGaw v. State, r23 Ohio St. I96, 174 N.E. 74 I (I93I); State v. Peoples, ro6 W.Va. 262, I45 S.E. 389 (I928). 
his irrational belief. The difficulty is that this view ignores the implied assertion of belief. If the statement had taken the form, "I believe that I am Napoleon," and were offered to prove that the testator so believed, it would be generally conceded that the statement was hearsay, and receivable only because of an exception to the rule. The former assertion is simply a short method of stating the speaker's opinion or belief. Implied ${ }^{15}$ assertions seem to fall within the hearsay category as well as express assertions. The evidential use of a person's conduct whether verbal or nonverbal, to prove a state of mind, even if purely circumstantial, involves, though possibly to a less degree, one of the inherent dangers in hearsaythat is, the danger of intentional deception. A lie may be acted as well as told, though it may be more difficult to do so. A man may, of course, lie about his intention to go to "Crooked Creek." If he has sufficient reason, he may more effectively deceive us by good circumstantial evidence of his intention to go there. He might, to use Mr. Hutchins' language, pack his grip, buy a ticket, and board the " 2 :ro express" for Crooked Creek, in the presence of numerous witnesses, intending all the time to leave the train at an intermediate station. The danger of deception may be great or negligible according to the circumstances.

4. If, according to general experience, an apparently natural statement of a present state of mind, under conditions which are free from suspicion, usually corresponds with the actual state of mind of the speaker, then such statement may be received to prove the state of mind asserted, except so far as it may be excluded by the hearsay rule.

In other words, by hypothesis, the statement has sufficient probative value to be received if it can come in under an exception ${ }^{16}$ to the hearsay rule.

The law is well settled that for some purposes and under some conditions such statements are receivable. The development, scope, and ration-

Is Wright v. Tatham, 7 Ad. \& Ell. $3^{1} 3$ (1837). In this case Baron Parke observed: "The conclusion at which I have arrived is that proof of a particular fact, which is not of itself a matter in issue, but which is relevant only as implying a statement or opinion of a third person on the matter in issue, is inadmissible in all cases where such a statement or opinion, not on oath, would be of itself inadmissible."

${ }^{16} \mathrm{We}$ usually think of the hearsay rule as one certainly excluding any evidence falling within the definition, unless it fits an exception well recognized by existing decisions. This may be a convenient approach, because it is easier to classify and segregate the hearsay which has been admitted, than the indefinite mass of hearsay in general. It may be well to remember, however, that until comparatively modern times there was no general exclusion of hearsay. Some hearsay was excluded, and some was admitted. New problems resulted in new rulings of admission or exclusion. At any given time, the rule, i.e., some generalization, was correct only so far as it conformed to the decisions, and was not necessarily decisive of a new problem. Any rule must be subject to modification as new decisions multiply. 
ale of the exception, or exceptions, present fascinating problems which have been the subject of discussion by a number of eminent investigators. ${ }^{{ }^{77}}$ The present writer cannot hope to make a substantial contribution to the solution of these problems, but at most, to present some of the questions from a somewhat different angle.

Here, as elsewhere in the law of evidence, it may be helpful to trace the development of the rule which we attempt to rationalize.

From the earliest period some states of mind have been important in our law, but few, if any, questions as to how to prove them seem to have arisen prior to the eighteen hundreds. The person whose intention was in issue was nearly always unavailable because of death, or incompetency as a witness, and this necessarily precluded direct proof.

Probably it was assumed that the states of mind, with which the courts were ordinarily concerned, manifested themselves in acts, and hence that proof of the act was all that was needed to enable the jury to find the necessary intention.

In most cases of larceny, the proof of the taking and the conditions under which it was done left little room for doubt as to the animus furandi. In general it was highly probable that the man who burned or tore up his will intended to revoke it.

Likewise it was a natural conclusion that the embarrassed debtor, who suddenly went to France, did so with the intention of avoiding annoying suits and arrests, although of course it may have been merely a case of the tired business man seeking relaxation. In this earlier period, mental states in issue must have been proved circumstantially by evidence which was thought to be unobjectionable, otherwise some questions would have been preserved in the reports.

Early in the eighteen hundreds we begin to find questions raised as to the use of declarations or statements to prove a state of mind in issue. The language of the courts indicates that they did not realize that they were dealing with hearsay, but thought of a circumstantial use of words where the statements could be connected with the act so as to fall under the vague description of "a part of the res gestae." The idea of statements as conduct or behavior appears in Lord Ellenborough's opinion in one of the early cases ${ }^{18}$ for the alienation of the wife's affections:

77 Seligman, An Exception to the Hearsay Rule, 26 Harv. L. Rev. 146 (rgra); Chafee, The Progress of the Law-Evidence, 35 Harv. L. Rev., loc. 443 (I922); Maguire, The Hillmon Case -Thirty Three Years After, 38 Harv. L. Rev. 709 (r925); Hutchins and Slesinger, State of Mind in Issue, 29 Col. L. Rev. $\mathrm{I}_{47}$ (1929); Hutchins and Slesinger, State of Mind to Prove an Act, 38 Yale L. Jour. 283 (I929).

is Trelawney v. Coleman, r Barn. \& Ald. go (1817). 
What the husband and wife say to each other is, beyond all question, evidence to shew their demeanor and conduct, whether they were living on better or worse terms; what they write to each other may be liable to suspicion; but when that is cleared up, that ground of objection fails.

The "res gestae" notion is thus expounded by Lord Denman in one of the bankruptcy cases. ${ }^{\text {x9 }}$

The act and the intention were both necessary to be proved; and when the act has been proved by extrinsic evidence, it has been settled by cases so numerous and familiar that it is unnecessary to cite them, that the intent with which the act was done may be proved by the simultaneous declarations of the bankrupt. The principle of admission is that the declarations are pars rei gestae. (Italics supplied.)

For a long time the struggle was to bring the declarations within the saving grace of this elastic formula. ${ }^{20}$

This appears in the famous case of Rawson v. Haigh. ${ }^{2 \mathrm{I}} \mathrm{A}$ debtor had suddenly gone to France, professedly on a short business trip, leaving certain negotiations with some of his creditors unsettled. Some three weeks after reaching France he wrote that he was unwilling to return for fear that his creditors would cause his arrest, etc. In an action by his assignee in bankruptcy against a third person, it was necessary for the plaintiff to prove that the alleged bankrupt had departed the realm with the intention to hinder or delay his creditors. The letter was offered and received to prove the intention, and its admissibility sustained by the court in banc.

Today the analysis of the case seems simple. The letter was a natural hearsay assertion of his then present state of mind, i.e., apprehension or fear of hostile action by his creditors, admissible under the now established exception to prove the state of mind therein asserted, if a legitimate inference could be drawn from it as to the intention with which he left England. If at the time of writing he feared action by his creditors, it was

${ }^{9}$ Rouch v. Great Western Ry. Co., I Q.B. 5 r (I84r).

${ }^{20}$ This phrase, "res geslze," is used in so many different connections that no definite meaning can be ascribed to it. Some transactions consist entirely of words, as the making of an oral contract, the directions to an agent, the giving of notice and the like. Some transactions consist of a combination of acts and words. The handing over of a chattel to another is a gift or a bailment or a mere license to examine it, according to the words spoken at the time. Words spoken to another may furnish the explanation of the latter's act in response, as a warning of danger followed by some act to avoid it. Words at the time of an act may circumstantially indicate some mental state of the speaker. Words at the time of an act may directly or impliedly assert the purpose or intention of the speaker. Words spoken at the time of an exciting event may assert the speaker's perception of what has happened.

In these and divers other situations, the courts have described the words as a part of the transaction, and therefore admissible, without considering why. See Morgan, A Suggested Classification of Utterances Admissible as Res Gestae, 3 r Yale L. Jour. 229 (I922).

${ }^{2 \pi}$ Rawson v. Haigh, 2 Bing. 99 (1824). 
probable that he was in much the same frame of mind when he left three weeks before, especially in view of his embarrassed financial condition. If so, there was a fair probability that he left for the purpose of preventing the feared action by creditors-in short a hearsay step to prove a present state of mind as the basis for an inference as to a prior state of mind to prove the state of mind in issue.

The reasoning of Chief Justice Best was along quite different lines:

I am clear that they [the bankrupt's letters] were admissible. The going abroad was of itself an equivocal act, and where the act is equivocal, we must get at the motive with which it was committed. In ninety-nine cases out of a hundred, this can only be got at by the declarations of the party himself. . . . It is clear that a party must not be enabled to avail himself of declarations made at a time long subsequent to the act in question. The declarations, in order to be admissible, must be made, or the letter written, at the time of the act in question; but it is sufficient if they are written at any time during the continuance of the act; the departing the realm is a continuting act, and the letters were written during its continuance. (Italics supplied.)

Park, J., observed:

It is impossible to tie down to time the rule as to the declarations: we must judge from all the circumstances of the case: we need not go to the length of saying, that a declaration made a month after the fact would of itself be admissible; but if, as in the present case, there are connecting circumstances, it may, even at that time, form a part of the whole res gestae.

The courts doubtless were aware that a declaration or statement of intention, made at the very time of the act in question, had higher probative value to prove the intention than a similar statement where an appreciable amount of time intervened. Thus, if at the instant of tearing or burning his will, the testator should declare his intention to revoke it, or the debtor, at the moment of starting on his trip across the channel, should declare his intention to avoid his creditors, the problem of proof would be extremely simple. If the statement was accepted at its face value, as it naturally would be under those conditions, the intention was proved by a single step. Whereas a declaration of intention made some time before the act in question, even if accepted as representing the real intention at the time of speaking, necessarily involved a further step which was more doubtful, the inference or conclusion that the prior intention continued until the act was performed. Changed conditions or more deliberate reflection might easily produce a change of intention.

A testator in a moment of irritation might declare his intention to revoke his will, and then change his mind over night. A debtor in a panic might determine to flee from his creditors, and then after taking stock of his affairs regain hope of meeting his obligations and abandon his hastily formed intention to escape. 
Usually the degree of certainty to which a conclusion is proved decreases with the number of steps involved.

Further, an assertion of intention at the time of such an act had a certain circumstantial guaranty of sincerity which is frequently lacking in declaration of a mental state made at other times.

These considerations may have led to the notion that declarations which could be classed as a part of the res gestae were not hearsay.

Today it would not be contended that an extra-judicial assertion used to prove the truth of what is expressly or impliedly asserted, ceases to be hearsay because it may have high probative value, though such value may furnish some reason for making an exception in its favor.

A dying declaration, made under an unqualified belief that death is immediately impending, is none the less hearsay, though it may have the highest guaranty of sincerity. And so it is in a number of the other exceptions to the hearsay rule, such as entries and statements against interest and entries in the regular course of business routine.

By the middle of the century the notion that a declaration of a mental state was admissible only on some circumstantial theory because it was a part of the res gestae, i.e., an inseparable part of the act or conduct in question, seems to have been supplanted by the simple theory that declarations were good evidence of intention.

In Whiteley v. King in order to rebut the presumption of revocation of a missing will, declarations of the testator, expressing satisfaction with his will, had been offered and received. The objection to these declarations because they did not accompany any act was thus disposed of by Chief Justice Erle:

The declarations of the testator are cogent evidence of his intentions. In this case his repeated declarations down to within a very few days of his death, were abundant evidence that the testator did not intend to cancel or destroy the will. .... If declarations are evidence of intention, - as the cases cited show they are,- - there was abundant evidence to satisfy the jury here that the testator had no intention to cancel or revoke the will and codicil.

Justice Byles still clung to the res gestae theory, observing:

I see no reason why the declarations of the testator should not be admitted as part of his conduct, to show his intention as to the disposition of his property. (Italics supplied.)

In the United States declarations to prove a mental state in issue were admitted on some vague res gestae theory, though the courts were sometimes conscious that the evidence very closely resembled hearsay.

2 Whiteley v. King, $x 7$ C.B. [N.S.] $75^{6}$ ( 1864 ). 
In one of the early cases ${ }^{23}$ an action had been brought for persuading the plaintiff's servant to leave his employment. The defense was that the servant left for reasons of his own.

For this purpose the defendant was permitted to prove that the day before his departure the servant made certain statements about his financial difficulties and his fear of arrest, and of his desire to leave in order to see about his affairs. In approving the admission of this evidence, Upham, J., observed:

The testimony of the witness to mere declarations of the servant could not certainly be evidence; for the servant himself should be produced, ${ }^{24}$ and proof of his sayings would be rejected on the general rule respecting hearsay evidence. There are, however, exceptions to the general rule. Where the declarations of an individual are so connected with his acts as to derive a degree of credit from such connection, independently of the declaration, the declarations become part of the transaction, and are admissible in evidence.

Apparently the court did not think that the admission of such declarations constituted an exception to the hearsay rule, but rather that the exceptional circumstantial guaranty took them out of the hearsay class.

An important exception to the hearsay rule was thus evolved more or less unconsciously. In certain types of cases where the intention was doubtful, the courts felt the need for admitting such evidence and the obscurity of the res gestae phrase prevented them from perceiving a clear collision with the hearsay rule as then formulated. As already pointed out, the dividing line between a circumstantial and a hearsay use of words is often blurred, and the step beyond this obscure boundary was taken in the dark.

Where a mental state is in issue no serious criticism has been made of this newly established exception. The thing had to be proved somehow, and other evidence was frequently lacking or inadequate. And, according to the general experience of the courts declarations of the state of mind, when made at, or near, the time of the act, were usually reliable.

From declarations to prove a mental state in issue, the courts unconsciously took the next step which has recently given rise to so much dis-

${ }^{23}$ Hadley v. Carter, 8 N.H. 40 (I835).

24 In a modern case, Elmer v. Fessenden, ${ }_{5}$ I Mass. 359, 24 N.E. 208 ( 1890 ), involving a similar question, statements of departing employees had been admitted to prove their reasons for departure. On the point that they should have been called, Justice Holmes observed: "We can not follow the ruling at nisi prius in Tilk v. Parsons, 2 C. \& P. 20r, that the testimony of the persons concerned is the only evidence to prove their motives. We rather agree with Mr. Starkie, that such declarations, made with no apparent motive for misstatement, may be better evidence of the maker's state of mind at the time, than the subsequent testimony of the same persons." 
cussion-the admission of declarations to prove a mental state to prove a subsequent act.

In one of the earliest cases, ${ }^{25}$ where the question was whether an interlineation in a will had been made before or after its execution, prior declarations of intention on the part of the testator to dispose of his property in accordance with the subsequent instrument as interlined were admitted to prove that the interlineation was probably made at the time of execution, as otherwise the will would not have corresponded to his declared intention.

Lord Campbell, after reviewing a number of cases where declarations of intention had been received to prove a state of mind in issue, sustained the admissibility on the following ground:

Upon the whole, there being no authority adverse to the defendants, analogous cases being in their favor, and the admission of the contested evidence appearing to us to be conducive to truth and justice, we are of opinion that it was rightly admitted.

This development was almost inevitable. After it had once been established that declarations were admissible to prove the intention of the declarant, when involved in the issue, it was only natural to use them wherever intention was the proper subject of proof, though not an ultimate ${ }^{26}$ fact.

The necessity of proving a mental state in issue doubtless influenced the courts to relax the hearsay rule under the cover of the "res gestae" phrase so as to admit declarations because frequently they were the only available means of proving it. When the process became familiar this unstressed and never clearly formulated reason was forgotten, and the courts began to invoke the broad generalization that declarations were good evidence to prove a mental state.

${ }^{25}$ Doe d. Shallcross v. Palmer, r6 Q.B. 747 (I85I).

${ }^{26}$ An illustration of this appears in the famous case of Sugden v. Lord St. Leonards, I Prob. Div. I54 (1876). The case involved difficulties in proving the contents of a missing will. The direct evidence was furnished by an interested legatee. Corroboration was highly desirable. For this purpose declarations of the testator as to his intentions in respect to the disposition of his property were admitted. Lord Justice Mellish observed: "Wherever it is material to prove the state of a person's mind, or what was passing in it, and what were his intentions, there you may prove what he said, because that is the only means by which you can find out what his intentions were. When a doubt is thrown on the correctness of evidence which has been given as to the contents of a will, the declarations of the testator as to what he intended to put in his will, made either contemporaneously with, or prior to the execution of his will, are obviously evidence which may corroborate other testimony as to what is contained in the will. But, to my mind, they do not of themselves prove what were the contents of the will, they only corroborate the other evidence which has been given of the contents, because it is more probable that the testator has than that he has not made a particular devise, or a particular bequest, when he has told a person previously that he intended to make it, inasmuch as it shews that he had it in his mind to make such a will at the time he made that declaration. But a declaration 
The same sort of development had taken place in some of the other exceptions to the hearsay rule.

Doubtless necessity was the basis for the admission of reputation to prove the location of a public boundary when that was in issue, since it antedated the memory of living witnesses. Yet in later times reputation was admitted to prove the location of a public boundary to prove the location of a private ${ }^{27}$ boundary which coincided with it.

The difficulty of tracing relationship back for any considerable length of time is doubtless the reason for the exception admitting family hearsay to prove birth, marriage, and death in pedigree cases, but in the United States such hearsay is now commonly admitted to prove that class of facts, though pedigree is not an issue. ${ }^{28}$

In the United States, the step from declarations to prove a state of mind in issue to declarations to prove a state of mind to prove an act, was probably influenced by the broad statement in Greenleaf ${ }^{29}$ that,

Wherever the bodily or mental feelings of an individual are material ${ }^{30}$ to be proved, the usual expressions of such feelings, made at the time in question, are original evidence. If they were the natural language of the affection, whether of body or mind, they furnish satisfactory evidence, and often the only proof of its existence.

According to this passage, expressions of a mental state are characterized as original evidence, i.e., not second hand, and the necessity for using this somewhat questionable source of information is the frequent lack of other proof of such mental state, rather than the necessity of proving the mental state in question because involved in the issue.

Even if it were possible in the present state of the digests, no useful pur-

after he has made his will, of what the contents of the will are, is not a statement of anything which is passing in his mind at the time; it is simply a statement of a fact within his knowledge, and therefore you can not admit it unless you can bring it within some of the exceptions to the general rule, that hearsay evidence is not admissible to prove a fact which is stated in the declaration. It does not come within any of the rules which have been hitherto established." A majority of the judges of the Court of Appeal not only sustained the admission of the prior declarations of intention, but also the post testamentary declarations of the contents, thus starting another exception to the hearsay rule in the case of lost wills.

This latter phase of the St. Leonard's case and its effect in the United States is beyond the scope of this paper. Some comments on that subject appear in a note by the present writer in I9 Ill. L. Rev. 577 (1925) on the Admissibility of Statements by a Testator That He Had Revoked His Will.

${ }^{27}$ Thomas v. Jenkins, 6 Ad. \& Ell. 525 (1837).

${ }^{28}$ In re Hurlburt's Estate, 68 Vt. 366,35 Atl. 462 (r896).

${ }^{29}$ I Greenleaf, Evidence ( $2 \mathrm{~d}$ ed. I 844 ), § I02.

$3^{\circ}$ The author may have used "material" in the sense of legally material, i.e., in issue, but if so, this limitation was not noticed by the profession. Greenleaf's treatment of hearsay makes it extremely unlikely that he had in mind any distinction between evidence to prove a fact in issue, and evidence to prove a fact relevant to a fact in issue. 
pose would be served by attempting to collect all of the earlier American cases in which declarations of intention were admitted to prove subsequent conduct.

In nearly all of them which have come to the writer's attention, the magic phrase "res gestae" solved the difficulty without the trouble of discussion. There are a few early cases $^{3 \mathrm{x}}$ where the declarations by the victim of a crime were admitted to prove his subsequent conduct.

A fairly early Pennsylvania case ${ }^{32}$ sanctioning the use of declarations of intention to prove an act is unique in that the court rejected the res gestae theory and sustained the admission of the evidence because of its corroborative value, on much the same reasoning as that employed by Lord Justice Mellish in the later case of Sugden v. St. Leonards. ${ }^{322}$

In the former case the action was against the master for the acts of his agent and servant in cutting a dam whereby the plaintiff's logs had been washed away. The direct proof to identify the persons who cut the dam left that matter in considerable doubt. The court admitted proof of prior declarations by the agent of his intention to cut the dam in order to float out some logs belonging to the defendant.

Sharswood, J., thus sustained the admission of the evidence:

It was objected to on the ground that such declaration of the agent was no part of the res gestae, and, therefore, upon the familiar and well-settled rule of evidence, not admissible against his principal. But clearly this rule has no application. The declaration was offered not as in itself affecting the principal, but in corroboration of the other testimony in the cause that McDougall and Charles Grinnell, his workman, were seen to go to the mill together-that Grinnell soon after was observed on the dam with an axe and that he appeared to be chopping something. Now, when the question is whether a person has done a particular thing, and some evidence of it has been given, it is surely competent to show in corroboration that he had avowed his purpose beforehand.

${ }^{3 \mathrm{~S}}$ State v. Howard, $32 \mathrm{Vt}$. 380 '( 1859$)$, admitting the declarations by the deceased victim of an abortion of her intention to have an abortion performed; State v. Vincent, 24 Ia. 570 (I868), admitting the declarations of the murdered man as to where he intended to go. Hunter v. State, 40 N. J. L. 495 (I878), admitting declarations by the deceased of his intention to go to a certain place with defendant. Several recent cases involve similar situations: Comm. v. Marshall, 287 Pa. 512, ${ }_{35}$ Atl. 3 or (1926), statement by the victim of her intention to go to the defendant's office; State v. Mayer, ${ }_{54}$ Wash. 667, 283 Pac. I95 (1929), statement by the victim of his intention to return; State v. White, 52 Nev. 235, 285 Pac. 503 (I930), statement by the victim of his intention to go to see the defendant; State v. Lang, ro8 N. J. L. 98, 164 Atl. 864 (I93I), statement by the victim of his intention to go to a certain place with the defendant; State v. Journey, rr 5 Conn. 344, I6r Atl. 5 I5 (r932), statements by the victim of his intention to go to work at the defendant's place. But see Mills v. Comm. $240 \mathrm{Ky} \cdot 359,42 \mathrm{~S}$.W. (2d) 505 (193I), excluding statement by victim of his intention to go to work with defendant.

${ }^{32}$ Dodge v. Bache, 57 Pa. 42 I (1868).

${ }^{32 a}$ See quotation,-note 26, supra. 
Probably the most frequent use of declarations of intention to prove subsequent conduct occurred in homicide cases where uncommunicated threats by the deceased were admitted on the issue of self-defense to prove the deceased the probable aggressor. In an early Illinois case ${ }^{33}$ the court reasoned thus:

This evidence [of threats] the court ruled out, and an exception was taken. In this the court unquestionably erred, although they may never have come to the knowledge of the defendant till after the homicide was committed. If the deceased had made threats against the defendant, it would be a reasonable inference that he sought him for the purpose of executing those threats, and thus they would serve to characterize his conduct toward the prisoner at the time of their meeting, and of the affray.

Similar rulings followed in a number of the states, 34 though it is doubtful whether the courts realized that they were using hearsay, because of the confusion created by the res gestae phrase; 35 and Greenleaf's statement that declarations of a mental state were original evidence.

Messrs. Hutchins and Slesinger warn us on psychological grounds that threats to assault or kill, etc., are frequently very weak evidence of an intention to do so. Or, as they prefer to put it, the correlation between threats and the threatened action is not high, because the speaker may have been merely giving vent to momentary resentment or wounded feelings. The courts have apparently been aware of this weakness, and in the case of uncommunicated threats by the deceased, have usually required a substantial independent showing of aggression as a basis for this corroborative evidence.

The question of uncommunicated threats to prove the deceased the aggressor came before the Supreme Court of the United States in the Wiggins case. ${ }^{36}$ Without any particular discussion, the court held them admissible for this purpose on the authority of a number of cases in the State courts, and a statement from Wharton that threats by the deceased were relevant to show that he was seeking the defendant's life. Mr. Justice Clifford dissented on the ground that there was not sufficient evidence of self-defense. The hearsay problem was not discussed. The question of relevancy would seem to be obvious.

33 Campbell v. People, 16 Ill. 17 (1854).

34 People v. Arnold, 55 Cal. 476 (I860); Stokes v. People, 53 N.Y. I64 (r873); State v. Elkins, 63 Mo. I59 (1876); Roberts v. State, 68 Ala. 156 (1880); Roberson v. State, 217 Ala. $696, I_{1} 7$ So. 4I 2 ( 1928 ). The later cases are collected in I Wigmore, Evidence (2d ed. I923), 346,8 III.

35 For this sort of confusion see State v. Sloan, 47 Mo. 604 (I87x).

${ }^{6}$ Wiggins v. People of Utah, 93 U.S. 465 (I876). 
The judicial psychology is that expounded by Chief Justice Andrews in a later Connecticut case. ${ }^{37}$

The declaration of a party that he intends $3^{3}$ to do a certain act, or pursue a certain course of conduct, is always admissible when the issue is whether or not the party making the declaration did the act or followed the course of conduct, because the declaration proves that those feelings exist which prompt the act or the conduct.

Threats of suicide to prove suicide rather than murder encountered more difficulty. Perhaps the courts were dimly conscious of the general unreliability of threats of suicide. Many persons threaten suicide, and comparatively few carry the threat into execution. At any rate, the courts clearly perceived that they were asked to admit hearsay, and the analogy of uncommunicated threats by the deceased to kill the defendant was apparently not thought of or suggested.

The first case $^{39}$ belonging to this general class to come before the Supreme Judicial Court of Massachusetts was an abortion case resulting in death. The defendant claimed that the deceased herself caused the abortion, and offered proof of her statements of her intention so to do.

In sustaining the exclusion of this evidence the court observed:

The fact that the purposes and intentions of the deceased would be, if known, a material aid in coming to a correct conclusion, does not permit such purposes and intentions to be found upon incompetent evidence. . . . Perhaps in this may be found a satisfactory test of the competency of the testimony. If the government had called Hughes, and offered to prove by her that the deceased had told her in June that she was pregnant by the defendant, and he had agreed to perform the operation, would it be contended that the fact thus offered to be established could be proved by that evidence? There is no claim that the evidence is admissible under any other ${ }^{40}$ specific exception to the rule excluding hearsay.

${ }_{37}$ Mills v. Lumber Co., 63 Conn. I03, 26 Atl. 689 (I893).

${ }^{3}$ Apparently the courts use the term "intention" in the sense of a mental choice between possible alternative courses of conduct. For the present purpose it is not important to speculate as to whether volition enters into the choice, or whether it results mechanically from some balance of behavior patterns.

Professor Chafee speaks of intention as dynamic, which seems to suggest that he thought of it as an impelling factor in the subsequent conduct. This gets us into unprofitable speculation. A intended to visit his dentist and carried out his intention. He also intended to go on a fishing trip, and did so. It may be doubted whether his intention in either case had much, if any, influence in bringing about his subsequent acts. Very likely something antecedent was the stimulus that produced both the intention and the intended acts. We may agree that until the intention is formed, action is not likely, and when the choice is made, corresponding action usually follows. For our purpose, the important thing is the correlation, whether we know the cause of it or not, between the intention and the subsequent conduct, and the correlation between the intention and words asserting it.

${ }^{39}$ Comm. v. Felch, ${ }_{3} 2$ Mass. 22 (I882). The English Court of Appeal reached the same result on a similar state of facts, Rex v. Thompson, [rgז2] 3 K.B.D. I9.

$4^{\circ}$ In the omitted passage the court had discussed the exception admitting declarations to prove pedigree, though its bearing on the case is beyond conjecture. 
The court apparently saw no distinction between a statement of a present intention to prove an act and a statement of a past objective event to prove such event. Whether the same rule of admissibility or exclusion should be applied to both varieties of statements will be discussed later.

The ruling in the Felch case was for a time followed in a number of suicide $^{4 x}$ cases. It was later repudiated in Massachusetts and Missouri, ${ }^{42}$ and such threats are now usually admitted. ${ }^{43}$

Threats by a third person to commit the crime to prove him guilty rather than the defendant are less favored, ${ }^{44}$ though it is difficult to see any substantial distinction. Under substantially similar conditions the intention of $\mathrm{X}$ to kill $\mathrm{Y}$ has the same probative value to prove his probable conduct, whether $\mathrm{X}$ happens to be killed, as in the self-defense cases, or whether $\mathrm{Y}$ is the person killed.

The recent discussion of such problems has centered around the Hillmon case. ${ }^{45}$ To most readers the facts of that case are familiar. The plaintiff sued on several life-insurance policies, alleging that Hillmon, the insured, had been accidentally killed at Crooked Creek, and his body there buried. The defendants claimed that a man named Walters was the person killed and that it was his body that was buried at Crooked Creek, and later exhumed for identification. The evidence identifying the body was in sharp conflict. There was at least substantial proof that the body was that of Walters. The defendants offered two letters written from Wichita by Walters, shortly before his disappearance, one to his sister and one to bis fiancée, stating that he was going on a trip to Colorado with Hillmon. These letters were excluded by the trial court. The Supreme Court reversed this ruling. Mr. Justice Gray gave the following reasons for admitting the letters in question:

A man's state of mind or feeling can only be manifested to others by countenance, attitude or gesture, or by sounds or words, spoken or written. The nature of the fact

${ }_{4 \mathrm{I}}$ Siebert v. People, I43 Ill. 571, 32 N.E. 43I (I892); State v. Punshon, I 24 Mo. 448, 27 S.W. IIII (r894).

${ }_{42}$ Comm. v. Trefethen, I57 Mass. I80, 3 I N.E. 96 I (I892); State v. Ilgenfritz, ${ }_{26}{ }_{3}$ Mo. 6I5, I73 S.W. 104I (I915).

43 Bowie v. State, 49 S.W. (2d) ro49 (Ark. 1932). State v. Prytle, Igr N.C. 698, 132 S.E. 785 (1928); Comm. v. Santos, 275 Pa. 515 , I 19 Atl. 596 (I923), and cases therein cited. The cases in Illinois are in hopeless confusion; see the discussion of the suicide cases in Greenacre v. Filby, 276 Ill. 294 , I 14 N.E. 536 (IgI6), in which the court approved the rejection of declarations by a deceased person of his intention to go to see his parents, because they were made several hours before leaving and therefore were not a part of the res gestae.

${ }^{44}$ Arnold v. State, $x 79$ Ark. I066, 20 S.IW. (2d) I89 (1929). The cases involving threats by a third person are collected in I Wigmore, Evidence (2d ed. x923), $\$$ I40.

45 Mutual Life Ins. Co. v. Hillmon, 145 U.S. 285 , 12 Sup. Ct. 909, 36 L. Ed. 706 (1892). For an elaborate statement of this case, see Maguire, The Hillmon Case-Thirty-Three Years After, 38 Harv. L. Rev. 709 (I925). 
to be proved is the same, and the evidence of its proper tokens is equally competent to prove it, whether expressed by aspect or conduct, by voice or pen. When the intention to be proved is important only as qualifying an act, its connection with that act must be shown in order to warrant the admission of declarations of intention. But whenever the intention is of itself a distinct and material fact in a chain of circumstances, it may be proved by contemporaneous oral or written declarations of the party.

The existence of a particular intention in a certain person at a certain time being a material fact to be proved, evidence that he expressed that intention at that time is as direct evidence of the fact, as his own testimony that he then had that intention would be . . . and while he is still alive, his own memory ${ }^{46}$ of his state of mind at a former time is no more likely to be clear and true than a bystander's recollection of what he then said, and is less trustworthy than letters written by him at the very time and under circumstances precluding a suspicion of misrepresentation.

The letters in question were competent, not as narratives of facts communicated to the writer by others, nor yet as proof that he actually went away from Wichita, but as evidence that, shortly before the time when other evidence tended to show that he went away, he had the intention of going, and of going with Hillmon, which made it more probable both that he did go and that he went with Hillmon, than if there had been no proof of such intention.

The opinion cites a considerable number of cases, all but two ${ }^{47}$ of which involved the use of declarations to prove a state of mind in issue. If counsel for the insurance company had been more resourceful they might have cited quite an array of cases furnishing strong analogies, particularly the cases of uncommunicated threats to increase the probability that the deceased was the aggressor. The Supreme Court only two years before had considered the case of threats by a third person ${ }^{48}$ and apparently thought the evidence admissible, though the point was left undecided.

The Dodge v. Bache case ${ }^{49}$ decided by an eminent judge of the Supreme Court of Pennsylvania was very much in point. Apparently the court was strongly inclined in favor of the evidence and thought that the cases actually cited furnished ample justification in point of authority for its admission. While the precise state of facts presented in the Hillmon case was new, the admission of declarations of intention to prove or corroborate other proof of an act clearly was not a novelty in the United States in I892.

${ }^{6}$ This is obviously a paraphrase of the statement by Justice Holmes in Elmer v. Fessenden, later cited in the opinion. For the original statement by Justice Holmes, see note 24, supra.

47 Sugden v. St. Leonards, I Prob. Div. I54 (1876) (see note 26 , supra) and Hunter v. State, 40 N.J.L. 495 (1878). In the Hunter case the court approved the admission of statements by the victim of a murder of his intention to go to another town with the defendant, presumably to prove that he was with the defendant when killed. The report is not clear on this point. For the recent cases on this point, see note $3 \mathbf{I}$, supra.

${ }^{8}$ Alexander v. United States, 138 U.S. 353, xx Sup. Ct. 350, 34 L. Ed. 954 (I89I).

49 Dodge v. Bache, 57 Pa. 421 (1868). 
Nine years later the same court, without noticing the Hillmon case and without dissent by Justice Gray, disposed of another dramatic case ${ }^{50}$ involving declarations by a testator to prove his intention to prove that his signature to a will which did not correspond with such intention was probably forged, on grounds which would have equally excluded the declarations of intention in the Hillmon case. The declarations to prove intention in the Throckmorton case were of too little value ${ }^{50 a}$ to be worth considering and might well have been held inadmissible on that ground, but Mr. Justice Peckham placed the exclusion on much broader reasons:

After much reflection upon the subject, we are inclined to the opinion that not only is the weight of authority with the cases ${ }^{51}$ which exclude the evidence both before and after the execution, but the principles upon which our law of evidence is founded necessitate that exclusion. The declarations are purely hearsay, being merely unsworn declarations, and when no part of the res gestae are not within any of the recognized exceptions admitting evidence of that kind. .... But if the matter in issue be not the mental capacity of the deceased, then such unsworn declarations, as indicative of the state of his affections, are no more admissible than would be his unsworn declarations as to any other fact.

In the Hillmon case the court approved declarations of intention to prove intention to increase the probability that such intention was carried out. In the Throckmorton case the same court disapproved declarations of intention to prove intention to decrease the probability that a contrary intention was carried out. In both cases the declarant was unavailable, so that the conflict is reduced to its simplest form.

The first question then is whether an exception to the hearsay rule can be justified in favor of declarations of intentions to prove the probable performance of the act intended. It must be assumed, of course, that under the circumstances in any given case, the intention, if proved by competent evidence, would fairly warrant an inference that the intended act was done. If the intention would not sustain that inference, no problem would arise as to the means of proving intention. In that event any and all proof of intention would be excluded as irrelevant.

If we accept the view that the hearsay rule should and does exclude declarations of intention to prove that the testator did, or did not, sign the

${ }^{50}$ Throckmorton v. Holt, I80 U.S. 552, 21 Sup. Ct. 474,45 L. Ed. $66_{3}$ (Igor).

son It appears from the report of the case in the Court of Appeals of the District of Columbia, I2 D.C. App. $55^{2}$ (I8g8), that the statements of the testator were of a very general character and remote in time from the date of the alleged forged will.

${ }^{5 x}$ In State v. Ready, 78 N.J.L. 599, 75 Atl. 564 (I9IO), the court reviewed the cases cited in Mr. Justice Peckham's opinion and noted that most of them were not in point. In the Ready case, which was a prosecution for the forgery of a will, the court held that declarations by the testator of his intention to dispose of his property in a certain way should have been admitted to rebut the charge. See also Atherton v. Gaslin, 194 Ky. 460, 239 S.W. 771 (I922). 
contested will, in a case where circumstantial evidence of intention would be received, consistency would force us to exclude Walters' letters stating his intention to go to Crooked Creek, though we would have no hesitation in admitting a letter from the insured to Walters requesting him to meet him there, on the theory that such a letter would probably produce an intention on Walters' part to go as requested.

In a missing will case, where the other evidence left it doubtful whether the instrument was destroyed by the testator or suppressed by a third person, we would be forced to exclude the testator's declarations of intention to revoke, or his expressions of satisfaction with his will. The Throckmorton case was a will case and is therefore inconsistent with a special exception in that field.

In the homicide cases where the other evidence left it doubtful whether the defendant or the deceased was the aggressor, we would exclude uncommunicated threats. Likewise in the homicide cases, where the contention was that the deceased killed himself, we would exclude threats of suicide. In all of these cases the objection would be the same, the use of hearsay to prove an intermediate probandum.

We know, however, as a matter of fact, that in all of the cases put the great majority of the courts for the last fifty years have been admitting declarations of intention. Consciously or unconsciously, an exception has been established for hearsay proof of intention in these constantly recurring situations. The Supreme Court of the United States may conceivably continue to exclude a testator's statement of his intention when not in issue, but it is extremely unlikely to reverse its ruling on uncommunicated threats. The Supreme Court of Illinois may continue to reject threats of suicide, but it is too firmly committed to the admission of a testator's statements of intention to change its rule in that particular, or to exclude uncommunicated threats by the deceased in cases involving self-defense. The Court of Appeals of New York may continue to follow Throckmorton v. Holt in cases of missing wills, ${ }^{52}$ but is not likely to reverse itself and exclude uncommunicated threats by the deceased on the issue of self-defense in homicide cases, or threats of suicide where the issue is murder or suicide.

Thus the rules of evidence in this field are full of inconsistencies. Every court admits declarations of intention to prove conduct in some cases and excludes them in others where they would be freely received by its neighbors, without any apparent reason for the distinction. It is too late to quarrel with these specific exceptions because they are thoroughly established by precedent. If they cannot be rationally justified, we may be 821.

${ }_{52}$ In re Staiger's Will, 243 N.Y. 468 , I54 N.E. $3^{\text {I2 }}$ (1926), commented on in 2 Ill. L. Rev. 
forced to accept them as accidental anomalies, and consistently oppose any extension. On the other hand, if these exceptions really rest on a sound basis, the rule should be extended to cover any case where similar conditions are present, i.e.:

(a) When, in connection with other evidence, proof of intention furnishes a reasonable ${ }^{53}$ basis for an inference that the intended action was carried out, or attempted to be carried out. This is merely saying that intention must have fair probative value to justify proof of it at all.

(b) When the declarations of intention furnish reasonably reliable evidence of the intention to be proved. According to the experience of the courts, an assertion of intention is thought to be reliable when it appears to be natural and spontaneous with no motive under the circumstances to deceive.

Since no question of memory is involved, the only danger is that of conscious or unconscious misstatement.

General experience seems to confirm the view that men rarely consciously misstate their intentions without some motive or reason, ${ }^{54}$ and hence if we cannot discover any motive, that danger is considerably decreased. Unconscious ${ }^{55}$ misstatement may undoubtedly occur, as in threats of violence or threats of suicide. If it is safe to receive such declarations, there is little cause to distrust such a declaration as that involved in the Hillmon case.

In the final analysis, any justification of a general exception in favor of declarations of intention to prove subsequent conduct must rest on a value judgment as to the positive advantage from the use of the evidence as compared with the dangers which a rule of exclusion would eliminate.

The obvious dangers of hearsay in general are these: (a) lack of per-

53 Intention alone is frequently an inadequate basis for a conclusion that the intended act was done, because there may be too many chances of accidental frustration. These possibilities, of course, vary very greatly according to the nature of the action intended and the steps necessary to its accomplishment. When I leave my house at 8:30 in the morning for a ten minute walk to the Law School to meet a nine o'clock class, the probability of accomplishment is high. If my neighbor leaves at the same time to keep an appointment in the Loop, the chances are somewhat less because of traffic conditions. It is easy to think of cases where the chances of accomplishment decrease to the vanishing point. The time element is also important because the intention may not continue. In the case of threats by defendant the courts have not always appreciated this objection, State v. Wright, I4I Mo. 333, 42 S.W. 934 (I899). But see State v. Wilson, 250 Mo. 323, I57 S.W. 313 (rgr3).

54 If the office boy announces his intention of attending the ball game on Sunday, the danger of misstatement is rather negligible. If he requests a day off to attend the funeral of a relative we might be suspicious.

${ }_{5 s}$ Hutchins and Slesinger, State of Mind to Prove an Act, 38 Yale L. Jour., 283, loc. 296 (I929). 
sonal ${ }^{6}$ knowledge by the declarant; (b) intentional ${ }^{57}$ misstatement by the declarant; (c) misleading statements because partial or incomplete; ${ }^{58}$ (d) unintentional misstatement from imperfect perception, or faulty memory. All of these dangers are real and substantial in most cases, and seem to justify a very general rejection of hearsay, though undoubtedly in some instances we thereby lose some valuable and much needed evidence. As between the general exclusion and the general admission of hearsay, the advantage seems clearly in favor of exclusion, especially when the evidence is to be dealt with by an untrained body of laymen in the hurry and stress of a trial.

Complete exclusion of hearsay would result in too great hardship in too many cases. As a compromise there are numerous exceptions in favor of fairly well-defined classes of hearsay. In nearly all of these exceptions there is, or is commonly thought to be, a real need for a relaxation of the rule because of the unavailability of the witness, or the difficulty of proving certain classes of matters by other means, and in such cases the hearsay admitted is, or is commonly thought to be, more reliable or less subject to the dangers of hearsay in general. Courts impressed with the soundness of the exclusion have not been inclined to create new exceptions because of analogies, but most of the exceptions have certainly been expanded in modern times. This is strikingly illustrated by the increasing use of the testator's statements about his will.

In the case of declarations to prove a mental state the dangers of hearsay are reduced to the minimum. There is no danger of lack of personal knowledge, or of faulty perception, or of failing memory, if we agree that a man is conscious of his own states of mind. The only danger is that of misstatement, which is greatly reduced by the apparent absence of motive to deceive. In short, because of the uncertainty and inadequacy of purely circumstantial evidence in a large number of cases, declarations of intention constitute the "best evidence that the nature of the case will admit."

True, we do not have the same need of proving intention to prove an act as we do where intention is in issue, but nevertheless there is a real need of proving intention because of its circumstantial value in otherwise doubtful cases. In such cases as the Hillmon case or State v. Journey, ${ }^{59}$

${ }^{56}$ Persons frequently make positive assertions on the basis of what they have been told or read or merely surmised, without any indication of this in the statement itself. This is familiar to everyone who has had occasion to interview witnesses or clients. Cross-examination furnishes the most effective protection against worthless statements of this sort.

57 Cross-examination furnishes more or less protection here according to circumstances.

${ }^{58}$ This is illustrated by the ancient story of the watchman at the crossing who told of waving his lantern at the approaching traveler but failed to add that the light had gone out. The need for cross-examination is obvious.

59 State v. Journey, Ir 5 Conn. 344, I6r Atl. 515 (1932). 
or Comm. v. Trefethen ${ }^{59 a}$ this sort of evidence of intention is preferable to no evidence on that subject at all. But the need is not confined to these particular instances.

Professor Maguire suggests several possible stopping points in the expansion of a general rule for the admission of declarations of intention to prove an act. However it is doubtful whether he has kept the circumstantial evidence problem and the hearsay problem as distinct as possibly they should be.

If, in a given case, intention has too remote a bearing on the issue, any kind of evidence to prove intention should be rejected for that reason. If, for example, Walters' intention to go west with Hillmon had no substantial value to increase the probability that he did so, because of the possibility that Hillmon might not permit him, then the problem of how to prove such intention would not arise. The possibility of Hillmon's refusal, of course, reduced to some extent the probability that Walters succeeded in carrying out his intention. If one does not agree with Mr. Justice Gray that, in spite of this possibility, proof of his intention made it more probable that he went with Hillmon, and it must be remembered that there was other evidence that Walters did succeed, it only indicates that there was room for a difference of opinion on a question of fact.

Wherever it is agreed that a given intention is proper to be proved, because substantially aiding in the determination of the ultimate question, declarations of intention are just as reliable proof of it, as similar declarations where the intention proved by them bears more directly on the issue.

Any other rule would lead to endless difficulties in application.

In most of the hearsay exceptions the admissibility of the statement depends on the unavailability of the declarant.

Should the same limitation be applied in the case of declarations to prove intention or other mental states? Where a state of mind is in issue, the accepted doctrine seems to be that the declarant need not be unavailable in order to admit proof of his declarations, on the theory that his contemporaneous statements when made under conditions which are free from suspicion, are more likely to correspond with his real state of mind than his subsequent testimony, ${ }^{60}$ which may be unreliable because of

59a Comm. v. Trefethen, 157 Mass. I80, 3 r N.E. 96I (I892).

${ }^{10}$ Hadley v. Carter, 8 N.H. 40 (1835); Elmer v. Fessenden, ${ }_{5}$ I Mass. 359, 24 N.E. 208 (r890). The same rule is generally applied where the declarations of an injured person are used to prove pain, Kennard v. Burton, 25 Me. 39 (1845); Northern Pac. Ry. Co. v. Urlin, I58 U.S. 27x, $x_{5}$ Sup. Ct. 840,39 L. Ed. 977 (1894); Board of Comm. v. Legett, Ir 5 Ind. 544, I8 N.E. 53 (r888). Contra, Roche v. Brooklyn Ry. Co., 105 N.Y. 294, I I N.E. 630 (r887), except where the exclamation is inarticulate or apparently involuntary. 
faulty memory or later bias. This seems fairly sound, if we can be sure that the declarations are correctly reported. In the bankruptcy case ${ }^{6 \mathrm{r}}$ already referred to, the bankrupt's letter asserting his fears of hostile action by his creditors seems more satisfactory evidence that he had that state of mind at that time than his subsequent testimony to the same effect, when he may have realized that it was to his interest to go through bankruptcy and thus get rid of his liabilities.

If the declarations must be proved by someone who heard them, there seems to be little choice. The witness' memory of the words may be faulty. The declarant's memory of his prior state of mind may be equally defective. Cross-examination is not very effective in either case.

In the cases involving a mental state in issue the relaxation of the usual requirement that the declarant be unavailable is not very important because in the great majority of cases the declarant is actually unavail$a_{b l e}^{62}$ by reason of death or incompetency as a witness, or is biased by interest.

If the same rule is carried over into the cases of intention to prove an act, and there is a certain advantage in uniformity, no serious danger is likely to arise. In the great majority of the cases the declarant will be unavailable. If available, he will usually be called to prove the act instead of his intention to do it. In cases where it is sought to prove that a third person committed a crime, or a tort as in Dodge v. Bache, even if he were available as a witness, it would usually be worse than useless to call him for any purpose.

If he denied the act, the prevailing rule against impeaching ${ }^{6_{3}}$ one's own witness would seem to preclude discrediting him by proof of his declaration of intention.

Even where the declarant is called as a witness to prove his act, it may become important to corroborate his testimony by proof of his prior declarations of intention. For example, a party to the suit may testify that he did a certain act, but his present interest, or other evidence, leaves the

\footnotetext{
6r Rawson v. Haigh, 2 Bing. 99 (I824). At this time the bankrupt would have been incompetent as a witness because of his supposed interest to support his bankruptcy.

${ }_{62}$ In Elmer v. Fessenden, I5I Mass. 359, 24 N.E. 208 (I890) it was doubtless possible to call the former employers to prove why they left, though it might have been inconvenient to do so.

In the cases involving pain, the declarant is usually available, but would certainly be biased because of interest.

63 People v. De Martini, 213 N.Y. 203, ro7 N.E. 5or (19r4); People v. Michaels, 335 IIl., 590, 167 N.E. 857 (1929). See Holtzoff, Impeachment by a Party of His Own Witness, 24 Col. L. Rev. 715 (I924).
} 
matter doubtful. Here corroboration ${ }^{64}$ by proof of prior declarations of intention may be desirable. Probably the main result of a requirement that the declarant be unavailable would be to exclude declarations of intention in a small number of cases where that kind of evidence is much needed for the purpose of corroboration. There are some other states of mind, such as fear or hate, which may, in a given case, fairly support an inference as to probable conduct, and when this is true the same means of proof should be available as in case of intention.

It has been suggested that if a man's statement of his then present intention is more satisfactory evidence of its existence than his subsequent testimony, then his statement of a present objective fact is by the same token more satisfactory than his subsequent testimony. For example, if a letter from X stating his intention to go to Crooked Creek is better evidence of such intention than his subsequent testimony that he so intended, his letter stating "I am in Crooked Creek today" is equally good evidence of that fact. This may be conceded, assuming the sincerity of the writer in both cases, and yet consistency does not force us to the same result. Awareness of present external conditions is doubtless a state of mind, and likewise a good circumstantial argument could be based on it. But we are practically certain that a jury would make a direct testimonial ${ }^{65}$ use of it.

64 This state of facts was suggested by the case of Dunham v. Cox, 8I Conn. 268 (xgo8). Though the court found it unnecessary to decide the point, there is a strong dictum in favor of this use of the declarations to corroborate the testimony of the declarant. See also State v. Young, II Mo. 495, 24 S.W. ${ }_{103} 8$ (I894) where it was held that defendant should have been permitted to prove his own prior declarations to show his innocent purpose in going to the place where the homicide occurred. Williams v. State, II 2 Tex. Cr. 482 , r7 S.W. (2d) I057 (I929), defendant's prior statements that he was going to repair a car.

is Hearsay, like testimony on the stand, furnishes direct proof of the proximate proposition sought to be established. This does not mean that there are no intervening steps of reasoning, but they are usually more or less unconscious. If a witness testifies that he perceived the happening of event $X$, the intervening steps are, from the veracity of the witness to his sensation of perception, and from perception to the probable existence of the event perceived. If his extrajudicial statement that he perceived the happening of event $Y$ is used for the same purpose the process is precisely the same.

If declarations of intention are used to prove the intention asserted, the proximate proposition that declarant then had such intention is thereby established, if the declarant is credible.

If declarations of declarant's present presence in $\mathrm{C}$ are used to prove such presence, that proposition is established in the same way.

If the proximate proposition happens to be the ultimate proposition also, its probability is greater, other things being equal, than where it is established by a line of proof involving circumstantial steps. Thus, the declarant's assertion of his presence in $\mathrm{X}$ may furnish more satisfactory proof of that proposition, than the same declarant's statement of his intention to prove his subsequent presence there. But there is no legal preference in favor of direct proof, and no general relaxation of the hearsay rule because the evidence is direct. We may use either cir- 
In all probability they would conclude that the writer was in Crooked Creek because he said so.

If it is objected that that is precisely what they do in cases of declarations to prove intention, the answer is that no one except the speaker knows his intention, and hence in most cases, in order to prove it all, we are forced to use his statements.

In general there is no such need to resort to direct hearsay to prove objective facts, though the need may exist in a particular case, or in certain types of cases.

Where the need exists for certain types of cases as, for example, to prove the items of a book account, or relationship in pedigree cases, an exception has usually been recognized in favor of what has been thought to be fairly reliable hearsay.

Where the need is peculiar to a given case, because of the accidental lack of other evidence, the courts in general have been unwilling to create new exceptions. This is the price we must pay for the hearsay rule if it is to remain workable at all.

There may be some justification for the reluctance of the courts to admit declarations to prove even present objective facts, because of the common opinion that there is more danger of misstatement than in case of statements of subjective conditions. The writer cannot venture an opinion on the soundness of this theory. Perhaps the psychologists may some day be able to enlighten us on this point.

There can be no doubt but that cross-examination is more effective when we are dealing with objective facts.

If the mental state exception should be extended to cover declarations of the declarant's awareness or perception of presently existing conditions, it would considerably enlarge the present exception for spontaneous statements, or "exclamations," as Dean Wigmore prefers to call them. According to the usually accepted theory, some exciting event in which the declarant is more or less involved, deprives him for the moment of all power of reflection and fabrication, and hence his statement of what he has just perceived is free of the danger of intentional misstatement.

As Lord Holt put it in an early case, ${ }^{66}$

What the wife said immediate upon the hurt received, and before she had time to devise or contrive anything for her own advantage; might be given in evidence.

cumstantial or direct proof, or both, so long as we do not collide with some specific rule of exclusion. We can not escape the hearsay prohibition on the ground that in the particular case hearsay has greater probative value than a line of circumstantial proof.

66 Thompson v. Trevanion, Skin. 402 (I694). 
But the same shock or excitement which deprives the observer of the ability to fabricate, is also likely to affect the accuracy of his perception. This has sometimes been pointed out by courts, ${ }^{67}$ and is discussed at length by Messrs. Hutchins and Slesinger. ${ }^{68}$

While this theory calls for an excited and almost hysterical declarant, there are respectable cases admitting statements of what was just perceived where the excitement apparently was not great. Thus, a statement of the declarant's recognition of a passing stranger as the person previously seen in the commission of a crime has been held admissible. ${ }^{69}$ Professor Morgan has collected a number of cases $^{70}$ where the event was not calculated to produce any appreciable excitement on the part of the declarant observer. But in all of these cases the declaration was oral and in respect to an event then taking place in the presence ${ }^{7 x}$ of the reporting witness, who could describe the conditions and thus enable us to judge whether the statement was the natural and spontaneous response to the external stimulus.

A written statement is necessarily deliberate, and we are therefore normally forced to rely entirely on the credibility of the writer, with no guaranty of his veracity except the apparent absence of motive to deceive. This has never been thought sufficient except where the nature of the thing to be proved forces us to this extremity. If the statement, "I am in Crooked Creek," had been made in the presence of witnesses, there would have been no occasion to use it to prove the presence there of the speaker, and no court would be inclined to stretch the "spontaneous exclamation" exception to the breaking point, without some real necessity. The absence of other evidence in a given case may create a need to use it in that case, but the logic of the Hillmon case does not open the door to its reception.

${ }_{67}$ The following charge to the jury was approved as a fair comment on the evidence in Inland Coasting Co. v. Tolson, r39 U.S. 55I, II Sup. Ct. 653, 35 L. Ed. 270 (r89I): "It may, at first, seem surprising that a man who himself wears the shoe should not be able to tell where it pinches; that a man who has his foot crushed should not necessarily know better than any other party where it was hurt, and how it was hurt; and yet it is not an uncommon thing for other men who saw the thing done, to be able to tell better than the man himself how the accident happened. The shock and pain may have the effect of rendering the man quite incapable of telling just exactly how the thing took place." In this instance the psychology of the judge seems to be in accord with that of the experts.

${ }^{68}$ Hutchins and Slesinger, Spontaneous Exclamations, 28 Col. L. Rev. 432 (1928).

${ }^{69}$ Lander v. People, I04 Ill. 248 (I882).

${ }^{70}$ Morgan, A Suggested Classification of Utterances Admissible as Res Gestae, 3 I Yale L. Jour. 229, loc. 237 (I922).

$\pi$ The problem of a telephone message stating the whereabouts of the speaker does not seem to have arisen, but the courts exclude the speaker's mere statement of his identity, State v. Berezuk, 55 S.W. (2d) 949 (Mo. x932). 
The argument that, because hearsay is admissible to prove the mental state called intention for a purely circumstantial use in proving subsequent conduct, therefore a statement of present objective facts, because it implies the mental state of awareness of them, is admissible to prove such facts, involves an obvious non sequitur.

Mr. Seligman argues, if the writer correctly understands him, that if declarations of intention are admissible to prove the doing of the act intended; they are logically admissible to prove a past act. If Mr. Seligman simply means that present intention is sometimes logically relevant to prove past acts or events, everyone will agree with him. And also, if it is permissible to prove present intention as the basis for an inference as to past acts or events, then it should be provable in the same way and by the same means as in the cases where the inference is as to subsequent conduct.

As a mere matter of logic and experience, $A$ 's declared intention to pay $B$ a sum of money on the first of the next month might naturally lead to the conclusion that $A$ had previously incurred an obligation to $B$, because that accords in general with experience.

In the Lloyd v. Powell-Duffryn Steam Coal Co. case, ${ }^{72}$ some of the Law Lords apparently accepted this perfectly logical reasoning without perceiving certain legal difficulties. The case arose under the English Workman's Compensation Act, and involved the dependency and paternity of an illegitimate child born after the death of the alleged father. The intention of the deceased to marry the mother was logically relevant to both issues. At least one of the opinions sustained the admission of declarations by the deceased of his intention to marry the mother to prove that he was the father of her after-born illegitimate child. The obvious argument was that he would not have intended to marry a woman in that condition unless he believed that he was responsible for it. As a matter of experience the conclusion as to paternity seems well enough founded. A very recent American case ${ }^{73}$ seems to involve a similar use of a mental state and was decided

72 Lloyd v. Powell-Duffryn Steam Coal Co. [1914], A.C. 733 .

${ }_{73}$ Shepard v. United States, 62 F. (2d) 683 (1933), certiorari granted May 29, 1933, 53 Sup. Ct. 794. See also Lindsey v. Lindsey, 147 So. 425 (Ala. I933), another inadequately considered case, presenting the problem of declarations to prove intention and belief to prove the absence of a past act by the declarant. It was charged that $D$ obtained $\$ 8,000.00$ from the deceased, either by raising a check for $\$ 8.00$ to that amount, or by undue influence. Declarations by the deceased after the date of the check were admitted to prove that he believed that he still had the fund and intended to divide it between his children. The supreme court of Alabama disposed of the objection by the following brief statement:

"Declarations of the decedent, subsequent to the date of this check, indicative of his belief that he still had this fund in the bank, and that he wanted his children to share it alike, were properly admitted in evidence, both on the issue of forgery and that of undue influence. Such 
without a clear appreciation of the problem. The defendant was tried on a charge of murdering his wife by poisoning. He had proved threats of suicide by the deceased. In rebuttal the government was permitted to prove statements by the deceased during her illness that her husband poisoned her, and this was sustained by the Court of Appeals on the ground that it rebutted the theory of suicide. It may be logically argued that she would not have believed that her husband poisoned her if she had voluntarily taken the poison with suicidal intent.

However, the admissibility of evidence does not depend on logical relevancy alone. It must avoid various legal rules of exclusion. The precedents admitting declarations of intention to prove intention as an intermediate probandum get us past the first barrier, but a more serious objection may shut out all proof of intention for this purpose. If we could ignore the tertium quid and simply take into account the high correlation, according to experience, between the present intention and certain past facts or events, no difficulty would arise.

But when dealing with the argument from present intention to past conduct or events, the courts generally refuse to permit us to take a short cut. They insist on premises something like these: "A would not intend to pay $\mathrm{B}$ unless he remembered or believed that he had previously incurred an obligation to him. If he remembered, or believed that such events happened, they probably did." Accordingly we are arguing from A's recollection or belief to the actual existence of the thing remembered or believed. The point here is not how recollection or belief may be proved, but the step from recollection to the thing recalled-from belief to the existence of the thing believed, and this involves a second collision with the hearsay rule, ${ }^{74}$ or a principle ${ }^{75}$ closely related to it. In the Wright v. Tatham case,

evidence was not subject to the hearsay rule, the only specific objection interposed." (Italics supplied.) On the issue of undue influence the mental state of the deceased was involved, and by all the precedents his statements were admissible to prove impaired mind and memory. On the issue of forgery the argument is quite different, i.e., from his belief in the continued existence of the fund to his lack of memory of the giving of the check, and if he did not remember it, he probably did not do it.

${ }_{74}$ Wright v. Doe d. Tatham, 7 Ad. \& Ell. $3{ }^{13}$ (1837); Gresham Hotel Co. v. Manning, I C.L. (Irish) 125 (1867). Professor McCormick has collected a large number of the cases dealing with this problem. McCormick, The Borderland of Hearsay, 39 Yale L. Jour. 489 (1930).

75 In all cases of testimonial evidence of past objective events, the witness may be thought of as stating, "I remember that I perceived X." The proof of the actual happening of $X$ rests on the propositions: If $\mathrm{W}$ remembered that he perceived $\mathrm{X}$, it is probable that he did perceive, i.e., have the sensation of seeing or hearing, $X$. If he perceived $X$, it is probable that it happened. The two sources of error, aside from intentional misstatement, are faulty memory and defective perception. The same statement out of court is obviously hearsay, if used to prove the same thing, and involves the same argument, and is accordingly generally excluded because, 
Baron Park gives a number of illustrations ${ }^{76}$ of opinion or belief, proved circumstantially, but rejected because of the hearsay rule.

If we reject belief, when proved by strong circumstantial evidence of conduct, to prove the existence of the thing believed, because of the desirability of cross-examination to test the soundness of the belief, consistency rather requires us to reject belief for this purpose when proved by less satisfactory ${ }^{77}$ means. Professor Maguire has so thoroughly covered this point that farther elaboration is useless.

The doctrine of the Hillmon case sanctioned one collision with the hearsay rule as a starting point for a purely circumstantial argument as to the probable subsequent behavior of an individual who had an intention to do something. The suggested extension involves a second and more serious collision because the question of the declarant's memory must be taken into account, or the unknown basis for his belief inferred from his statement.

In the case of some past acts of the declarant which might naturally account for his present intention, the danger of defective memory is slight. In the Powell case the declarant was not likely to be mistaken about his relations with the mother of the illegitimate child. But as to many past acts the memory of the declarant is as likely to be at fault as in regard to any other past facts. Everyone has had the experience of distinctly re-

in the absence of cross-examination, we have no safeguard against the dangers of these errors, though there may be strong reasons to believe that there was no intentional misstatement. This is illustrated by the rule excluding dying declarations to prove matters antecedent to the final difficulty, State v. Draper, $6_{5} \mathrm{Mo} .380$ ( 1877 ). When the recollection or belief of the unavailable witness is proved circumstantially, the subsequent steps in the argument are the same and involve the same sources of error for which we exclude verbal hearsay. Comm. v. Chickee, 186 N.E. 253 (Mass. 1933).

$7^{6}$ Wright v. Tatham, 7 Ad. \& Ell. 313 (1837). Baron Parke puts the following hypothetical cases of evidence clearly inadmissible because of the hearsay rule: The payment by a third person of a bet on an event to prove that the event happened; the payment of a loss by another insurer to prove that the loss occurred; the act of a sea captain in embarking with his family on a vessel after examining it to prove that the vessel was seaworthy.

77 Where recollection or belief is proved by conduct, the steps are these: testimonial proof of acts to prove inferentially the recollection or belief of the actor. Where recollection or belief is proved by intention more steps are necessary-testimonial proof of a declaration to prove intention to prove inferentially the recollection or belief of the declarant. The hearsay here is, of course, the same as in any other case of declarations to prove intention. This added step of hearsay makes the line of proof longer and weaker.

It has been argued that the circumstantial step from present intention to past recollection minimizes the danger of intentional misstatement which inheres in all statements of past events, because the declarant would not think of trying to mislead us as to the past by a false statement of his present intention. Granting the probative value of intention to prove recollection, it does not prove that uncross-examined recollection is a desirable means of proving the existence of the thing remembered.. 
membering that he did something or omitted to do something, and afterwards has been convinced that he was mistaken.

If the courts should sanction the inference from the recollection of the unsworn observer to the reality of the thing remembered, they would practically abolish the hearsay rule altogether, because the most positive assertion of a past fact or event, if really made on personal knowledge, amounts to a shorter way of saying "I remember that I perceived thus and so." The state of mind called memory is thus proved by the statement of it.

The recollection proves the perception, which in turn proves the existence of the thing perceived.

If statements of objective facts were limited to cases of deceased or otherwise unavailable declarants, it would amount to a judicial enactment of the Massachusetts statute. ${ }^{78}$ When account is taken of the ease with which oral declarations of deceased persons may be manufactured, the wisdom of such a radical innovation may be doubted.

So long as we have trial by jury as at present conducted, there is little likelihood that the courts will be led to extreme ${ }^{79}$ positions by any of the cases sanctioning the use of declarations of intention to prove subsequent conduct. On the contrary, most of the courts appear to be ultra-conservative in restricting such evidence to the specific fact situations for which there is abundant precedent.

${ }_{78}$ "A declaration of a deceased person shall not be inadmissible as hearsay if the court finds that it was made in good faith before the commencement of the action and upon the personal knowledge of the declarant." Mass. R. L. ( 1902$)$ c. $175, \$ 66$.

79 Since this article was written, the Supreme Court has reviewed and reversed the Shepard case (note 73 supra), Shepard v. United States, 54 Sup. Ct. 22, 78 L. Ed. 6 (Nov. 6, r933). In holding the statement by the wife inadmissible, Mr. Justice Cardozo uses this language: "So also in suits upon insurance policies, declarations by an insured that he intends to go upon a journey with another may be evidence of a state of mind lending probability to the conclusion that the purpose was fulfilled. Mutual Life Ins. Co. v. Hillmon, [supra]. The ruling in that case marks the high-water line beyond which courts have been unwilling to go. It has developed a substantial body of criticism and commentary. Declarations of intention, casting light upon the future, have been sharply distinguished from declarations of memory, pointing backwards to the past. There would be an end, or nearly that, to the rule against hearsay if the distinction were ignored.

"The testimony now questioned faced backward and not forward. This at least it did in its most obvious implications. What is even more important, it spoke to a past act, and, more than that, to an act by some one not the speaker. Other tendency, if it had any, was a filament too fine to be disentangled by a jury." 